\title{
Religious Studies and its Relationship with Theology: A Spatial Analysis ${ }^{1}$
}

\author{
KIM KNOTT \\ University of Leeds
}

\begin{abstract}
Academic disciplines can be understood as tribes with their own territories (Becher 1989) which are protected from outsiders and invested with power and meaning for those within. The language which scholars use to delineate and distinguish them from one another is replete with spatial metaphor and the language of war and struggle. References to inside/outside, inclusion/exclusion, to boundaries, incursions, incorporation, integration and embrace are frequently made, particularly when scholars write about their own discipline in relation to others. In this article I offer a spatial analysis of discourse about the discipline of religious studies and its relationship to theology. I note the importance in such discourse of the container schema (Lakoff and Johnson 1999) for depicting possible disciplinary relationships and various perspectives on 'religion' as an object of study. A spatial approach offers a clear visual depiction of the views of selected scholars of religion on the relationship of religious studies to theology, whilst also revealing some of the power strategies at work in disciplinary construction.
\end{abstract}

Keywords: Religious studies, Theology, spatial language, academic disciplines

Each tribe has a name and a territory, settles its own affairs, goes to war with the others, has a distinct language or at least a distinct dialect and a variety of ways of demonstrating its apartness from others. (F. G. Bailey from 1977, in Becher 1989, 1.)

This is a study of how those who devote their scholarly lives to understanding, analysing, discussing and interpreting 'religion' and everything associ-

\footnotetext{
${ }^{1}$ Thanks to the reviewers for their considered comments. Unfortunately, there was insufficient time to make the suggested changes. They will be borne in mind in any further work on this subject.
} 
ated with it name and order who they are and what they do. My approach is socio-spatial. I will use the tools that I have developed in recent years to locate 'religion' in ostensibly 'secular' spaces (Knott 2005a) in order to examine the nature of religious studies and its relationship to theology. ${ }^{2}$ This seems appropriate for two reasons: first, because the contemporary problem of the designation and disciplining of knowledge in relation to religion is a modern one arising in relation to debates since the Enlightenment about the nature and conceptualisation of 'religion', 'religions', the 'secular' and 'pluralism'. Secondly, in being a contested issue that involves professional communities and the institutional and discursive spaces in which they work, it is amenable to a socio-spatial analysis. ${ }^{3}$

\section{Space, Struggle and the Body}

As Henri Lefebvre stated in his ground-breaking book, The Production of Space,

No one can avoid trial by space [...] It is in space, on a worldwide scale, that each idea of 'value' acquires or loses its distinctiveness through confrontation with the other values and ideas that it encounters there. Moreover - and more importantly - groups, classes or fractions of classes cannot constitute themselves, or recognise one another, as 'subjects' unless they generate (or produce) a space. Ideas, representations or values which do not succeed in making their mark on space, and thus generating (or producing) an appropriate morphology will lose all pith and become mere signs, resolve themselves into abstract descriptions, or mutate into fantasies. (1991, 416-7.)

I suggest, following Lefebvre, that the debate about theology and religious studies and their relationship concerns the struggle to create and authorise

\footnotetext{
${ }^{2}$ This article is a development of lectures given at 'Theology and Religious Studies or Theology v. Religious Studies?', a conference held in June 2006 at St Anne's College Oxford, organised by the Higher Education Academy Subject Centre for Philosophy and Religious Studies, and at 'Study of Religion as a Discipline', a study day held in March 2007 at the University of Turku and organised by the Finnish Society for the Study of Religion and the Donner Institute.

${ }^{3}$ In this analysis I shall use the construction - the etic term - 'discipline' to refer to both theology and religious studies as separate bodies and communities of knowledge, even though many theologians and religious studies scholars employ the folk category or emic term 'field' (e.g. Anttonen 2004, 105-6; Corrywright \& Morgan 2006, 52; Ford 2005, 67-9; King (1990) in Wiebe 2005, 107; McCutcheon 1997, 28; Sutcliffe 2004, xviii). King \& Brownell, in their 1966 book The Curriculum and the Disciplines of Knowledge, described a 'discipline' as a community, a network of communications, a tradition, a particular set of values and beliefs, a domain, a mode of enquiry, and a conceptual structure (Becher 1989, 20).
} 
autonomous spaces - physical, mental and social. ${ }^{4}$ However, neither the process of disciplinary classification nor the socio-spatial struggle around it can be achieved in a vacuum, or without others to contend with. Religious studies - and theology - requires other bodies of knowledge in order to define itself, and needs other communities of scholars to debate and engage with. ${ }^{5}$ Russell McCutcheon illustrates this in his discussion of the construction of disciplinary space in Manufacturing Religion (1997). In his analysis of religious studies and the place of sui generis religion within it, he follows Michel de Certeau in stating that,

the claim of absolute distinctness and autonomy is the mark of a strategy that imposes a definition in order to create unique discursive and institutional places from which scholars exert power and control. The strategy's first task is to make such privileged zones possible, by demarcating, delimiting, and defining an ostensibly proper sphere of action and authority in relation to the previously existing and defined places of others. Thus, this self-created authority of the scholar has a place in which to act and a place from which to exert its exteriority over what is now considered external and foreign. What all these strategies have in common, according to Certeau, is that they function to exclude other voices and interests from a newly manufactured field by the very act of constituting that field in the first place. (McCutcheon 1997, 65.)

McCutcheon's allusion to a 'discursive strategy of containment and exclusion' at work in the disciplinary context of the study of religion is understandable in light of the anxiety surrounding the emergence of disciplines in the modern university. William Schweiker has suggested that 'every discipline had to have a specific autonomous, nonreducible subject matter which was nevertheless rationally consistent with all other disciplines' $(2006,140)$. As a result, scholars of religion, with a disciplinary object that could be reducible to psychology or sociology and open to conflation with theological interests, necessarily experienced the double anxiety associated with struggling to develop an autonomous, rational discipline and keeping it separate from theology.

\footnotetext{
${ }^{4}$ In this article I shall focus primarily on the 'mental', and to some extent 'social', spaces rather than the 'physical' ones. Further analyses could also be conducted of university departments of Theology, Religious Studies, and those that combine the two (physical and social space), and of professional subject associations and their conferences (largely social, but also physical and mental spaces).

${ }^{5}$ These include the social sciences and, increasingly, the cognitive and natural sciences.
} 
My approach from here on will be to examine the spatial language present in discourse about the discipline of religious studies and its relationship to theology. Bearing this in mind, if we were to reflect back on what I have said already, we would note that the aforementioned link between struggle, discipline and space is already emerging in the language and quotations I have used to introduce this paper. The use of such terminology is not accidental; it is deeply embedded in our cognitive and evolutionary constitution. As George Lakoff and Mark Johnson (1980) have pointed out, metaphors of containment (space) and warfare are primary figures of speech in English used for countless quite different contexts and purposes (cf. Thorne 2006). ${ }^{6}$

In addition to the link between space and struggle, Lefebvre makes another important connection with regard to the production of space, between body and space: 'The whole of (social) space proceeds from the body, even though it so metamorphoses the body that it may forget it altogether... The genesis of a far-away order can be accounted for only on the basis of the order that is nearest to us - namely the order of the body.' $(1991,405)^{7}$ Lefebvre's idea is important for explaining how we discursively construct and order our social world, and, in the argument presented here, our professional and scholarly world: the order of the body - so close that we cannot see it at work - is fundamental to the production of other orders and spaces.

The embodied realist agenda of Lakoff and Johnson (1999; Johnson 1987) helps to clarify this. They link our human bodies with the metaphors we use and our attempts at categorisation by means of the cognitive unconscious (1999). We are 'evolved to categorize', they say, categorizing as we do 'because we have the brains and bodies we have and because we interact in the world the way we do' (p. 18). We categorize on the basis of the body's regions: up/down, front/back, left/right. Furthermore, we distinguish inside and outside on this same basis. Others are 'outside' my body, but those who are closest in terms of kin and kind constitute 'we', the social body, the family, clan or tribe, which similarly has an 'inside' and a territory beyond which 'others' live, 'outsiders' with their own unknown identities and orders (Anttonen 1996). Between inside and outside there is a boundary. I will

\footnotetext{
${ }^{6}$ In this context, it is interesting to note Russell McCutcheon's choice of title, 'Dispatches from the "religion" wars' (2004), in which, like some other religious studies scholars such as Tom Lawson and Gary Lease, he uses the 'image of the disciplinary arena as a site of battle' (p. 161).

${ }^{7}$ Lefebvre was not the only scholar to make this connection, of course, and elsewhere in my work I have discussed the ideas of Kant, Foucault and others on this subject (Knott 2005a, 15-20; 2005b, 156-58).
} 
return later to this 'container schema', as Lakoff and Johnson call it, when examining the spatial language that scholars of religion use to talk about their discipline. Their principal point, however, is that 'our bodies define a set of fundamental spatial orientations that we use not only in orienting ourselves but in perceiving the relationship of one object to another' (1999, 35). So, in looking at the language that scholars use to talk about what they do and to distinguish themselves from others, I am starting from the body and its unconscious conceptual and categorical processes. As I hope to show by the end of the paper, this is an exercise in revealing, simultaneously, both the everyday nature of social classification and cultural organisation (Bourdieu 1988, xi), and also - because the notion of the 'sacred' can be attributed to the process of boundary-making and the distinguishing of bounded entities (Anttonen 1996, 43; 2005, 198) - the process of 'sacralization' at work in the making of disciplines. Both, I contend, are at work in the struggle within and between the disciplines of theology and religious studies and the discourse used to define and distinguish them.

My aim in looking at the language we use as religious studies scholars to describe our discipline or field and its relationship to others is, to use Bourdieu's words $(1988, x i)$, to 'exoticize the domestic' in order to interrogate that which is now so familiar that we rarely reflect upon it analytically.

\section{A Contemporary Introduction to the Study of Religion: A Socio-spatial Analysis}

As part of their scholarship, academics in religious studies have commented on the nature, form and mission of their discipline and its relationship to theology, whether by way of introduction to students or in methodological discussions with peers. What some of them have said provides the data for this analysis; their concepts and models become 'folk' or emic categories for this meta-analysis. Not that I can really claim much distance from these categories or their creators: I am one of them, after all. However, as an operational strategy I shall adopt the stance of a meta-outsider. In so doing, I am not endorsing the possibility of a 'position from nowhere' (Nagel, in Hufford 1999, 296). Rather, I am making the temporary and strategic move from 'inside' (the religious studies camp) to 'outside' the disciplinary camps of religious studies and theology, clutching the tools of my trade in order to assess the two parties and their relationships.

I turn first to a recently published collection of essays that currently informs the way in which students approach and think about our discipline: 
The Routledge Companion to the Study of Religion (2005). Here is what the editor, John Hinnells, has to say about it:

This book looks at the many perspectives from which religions may be viewed $[\ldots]$ Contrary to popular imagination there are many disciplines or approaches involved in the study of religions; each is discussed here in a separate chapter. The obvious routes are theology and religious studies, though there is much debate about the relationship between the two. In America there are indications of a growing difference, whereas in Britain the two appear to be coming closer together as can be seen in their respective chapters. $(2005,1 .)^{8}$

In light of the difference between America and Britain to which Hinnells refers, it is hardly surprising that this British scholar should choose to include both theology and religious studies in a book about the study of religion. However, it is important to note that chapters in a book cannot lie alongside one another; one must necessarily precede the other(s), and in this case it is theology that precedes religious studies. Hinnells organises the early chapters of his book as follows:

$\begin{array}{ll}\text { 1. } & \text { Why study religions? } \\ 2 . & \text { The study of religion in historical perspective } \\ 3 . & \text { Theories of religion } \\ 4 . & \text { Theology } \\ 5 . & \text { Philosophy of religion } \\ 6 . & \text { Religious studies } \\ 7 . & \text { Sociology of religion etc. }\end{array}$

Clearly, 'religion' is the book's focus, as the book title and the titles of the various chapters show, with the modus operandi being different academic perspectives on 'religion' (see Appendix, Fig. 1).

Introductory, historical and theoretical chapters are provided to situate the reader. Then comes the chapter on theology, followed by philosophy, then religious studies. Perhaps we should see the philosophy chapter as keeping theology and religious studies apart, like a referee, or as historically placed in a narrative about the development of disciplines, or as appropriately located in a continuum from theology (at the one end) to the social sciences (at the

\footnotetext{
${ }^{8}$ My italics. I shall use italics in the quotations that follow to indicate spatial concepts and metaphors.
} 
other) with philosophy and then religious studies situated in between. ${ }^{9} \mathrm{We}$ cannot say for sure what Hinnells had in mind in choosing this structure. Nevertheless, it is worthy of note that theology precedes religious studies. This might well be seen by some, such as Fitzgerald and McCutcheon, as an expression of the place still attributed in the academic study of religion - wittingly or unwittingly - to an 'ecumenical liberal theological' agenda (Fitzgerald 2000, 7; cf. McCutcheon 1997). Further, it is evident, as Figure 1 shows, that, in using a container metaphor or model for the study of religion, theology is included within some greater whole that also includes philosophy of religion, sociology of religion, psychology of religion and so on, as part of a poly-methodic field focused on 'religion'. The foregrounding of the category 'religion', the idea that such an object (with its institutions, beliefs, practices etc.) can provide the focus for disciplinary endeavour is, of course, a modern one that goes hand in hand with the emergence of notions of 'non-religion', or 'secularity', with its own beliefs and practices. This 'ideologically loaded distinction' (Fitzgerald 2000, 8), which mystifies the one - 'religion' - and naturalizes the other - the 'secular' - presenting the latter as 'the real world seen aright in its self-evident factuality' (p. 15), deserves more attention than I am able to give it here. Nevertheless, it is worth recalling the genealogical developments which have led to the emergence and centrality of the category 'religion' in the various models of religious studies that will be considered in this paper (cf. Asad 1993; McCutcheon 1997, 2003; Masuzawa 2005). 'Religion' takes the place of 'God' as we move from the focus of the theological enterprise to its religious studies counterpart. ${ }^{10}$

I shall turn now to the two essays in this volume, by David Ford (2005, 61-79) and Donald Wiebe (2005, 98-124), on theology and religious studies respectively. Both authors provide typologies which organise distinct approaches from the perspective of their discipline. My aim in discussing these is to examine the authors' use of spatial terminology, metaphors, typologies and their attention to relations in and between the two disciplines.

David Ford begins his essay by stating that, at its broadest, 'theology' (a term he concedes is not used in all religious traditions) 'is thinking about questions raised by, about and between the religions' $(2005,61)$. (See Fig. 2.)

\footnotetext{
${ }^{9}$ It is interesting to note that there is no chapter on the 'history of religion' as a perspective.

${ }^{10}$ See Smith on the concept of 'religion' and its role in establishing a disciplinary horizon: 'There can be no disciplined study of religion without such a horizon' (Smith 2004, 194). See Griffiths (2006) for a discussion of the (in)adequacy of 'religion' as a disciplinary object for 'not-theology'.
} 
This broad approach, like that of Hinnells in relation to 'the study of religion', is inclusive, potentially incorporating territory that religious studies scholars would see as part of their domain (i.e.,' 'questions about religions'). Is what we see here an attempt to include 'outsider' perspectives within theology, a discipline traditionally associated with 'insider' voices?

Like a number of other theologians, Ford differentiates the different branches of Christian theology practised in the modern university on the basis of geography, distinguishing between the German pattern, of confessional theology $(2005,65)$, the North American separation of theology and religious studies, confined respectively within the seminary or divinity school and the university department (p. 65), and the British pattern, the 'embrace',

In Britain university theology has become largely state-funded, and has developed from being exclusively Christian and Anglican to embracing, first, other Christian traditions, and then, in the later twentieth century, other religions. Departments in British universities are called variously theology, religious studies, theology and religious studies, and divinity. Whatever the name, most now embrace both theology and religious studies. (Ford 2005, 66.)

The British case is interesting because the suggestion here is that the institutional space afforded to religious studies has developed from within that previously allotted to Christian theology. ${ }^{11}$ Whilst Ford says in his final sentence that departments embrace theology and religious studies, his first states that it is theology that is doing the embracing. This corporal and social metaphor has the potential to be read and experienced as expansive and welcoming on the one hand, or as colonizing and oppressive on the other. What is clear though is that, within Britain at least, theology and religious studies are inter-linked in a complex historical, institutional and political relationship.

Ford's task in the Routledge Companion is to give an account of theology as one methodology within the study of religion. Developing the work of Hans Frei, he presents a five-fold typology of Christian theology based on the extent to which the five types are inside/outside with respect to the Christian faith (see also Ford 1999, 28-9). But Ford also comments on the discipline of religious studies in so far as it relates to the theological enterprise:

\footnotetext{
${ }^{11}$ Except in a few notable exceptions including the universities of Lancaster, Stirling, London (School of Oriental and African Studies) and the Open University.
} 
Religious studies has usually wanted to bracket out [...] any conception of God being involved in the knowing that goes on in the field; and its pursuit of questions of meaning, truth, beauty and practice has tended to be limited to the methods of its constituent disciplines. (Ford 2005, 67.)

In general, according for Ford, '[religious studies] treats Christian theology from the outside, coming to it with a mind [...] already made up and simply using it within its own framework where it fits' $(1999,21)$. But he evidently wishes not to foreclose so summarily on the relationship between theology and religious studies. His own hope is for 'integration' which he sees as a distinct possibility, at least within the British system. He notes the symbiotic nature of their relationship and uses spatial metaphors to develop his vision.

Theology is not in competition with religious studies but needs it. If theology is to be rigorous in pursuit of its questions of meaning, truth, beauty and practice then it needs to draw on work in other disciplines. This will not just be a matter of using their results when they are congenial, but rather of entering into them from the inside and engaging both critically and constructively with their methods and results [...] [Furthermore] religious studies need not be in competition with theology. Certain definitions of the field exclude certain definitions of theology [...] but other definitions of religious studies open it towards integration with theology. (Ford 2005, 68-9.)

The integrative approach he favours cannot, however, accommodate those forms of religious studies that insist on 'cutting off' enquiry and 'disallowing' potential theological answers (p. 69). Such a strong version of the discipline of religious studies would be neither congenial to his invitation to integration between the two nor open to the inclusion of theology within its own boundary. How, if at all, do the two conceptions of religious studies presented by Ford map on to the types presented in the same volume by the religious studies scholar, Donald Wiebe?

Wiebe offers an analysis of the ways in which some scholars have depicted religious studies in introductory books on the subject. ${ }^{12}$ Although he doesn't comment on it himself, we are able to see from his selection just how many use spatial terminology. Key ways in which it is employed are as follows: to juxtapose theology and religious studies ('differentiate', 'distinct from', 'exclude'), to show their differing relationship to 'religion' as the object of study ('instruction in religion', 'teach about religion'), and to reflect

${ }^{12}$ Donald Wiebe has written extensively about the nature of religious studies as a discipline and its position within the university (e.g., Wiebe 1998, 2000). 
the oft-cited poly-methodological nature of religious studies ('field', 'community of disciplines gathered around'). Although such discussions help to separate religious studies as a new enterprise emerging in the twentieth century academy from theological studies of religion, none begin to reveal the internal struggles within the new discipline. Not that Wiebe himself wishes to hide them, but many of those he quotes from, rather than recognising or clarifying such struggles, contribute to obscuring them and to the continued ambiguity of the very term 'religious studies' $(2005,123)$. As he suggests, quoting from the American scholars Myscofski and Pilgrim,

[r]eligious studies, however defined or wherever located, remains suspect in the eyes of many within the rest of the academy and continually finds itself marginalized or otherwise obscured due to the fact and/or perception of blurred boundaries between studying religion and being religious, or between education about and education in religion. (Myscofski \& Pilgrim in Wiebe 2005, 110.)

This 'problem' within religious studies with regard to its boundaries with theology and religious education, and implicitly its nature, motivation and objectives as a discipline, is reflected in Wiebe's own typology and analysis.

Wiebe identifies four different approaches under the designation of 'religious studies'. Although he does not articulate these spatially, they certainly have spatial implications (see Fig. 3).

He refers to his first type as 'theology under new management' (p. 116), religious studies as humanistic studies, including the study of questions of meaning and truth (see 1 in Fig. 3). Type 2 is tertiary religious education, in which the aim is to provide an experiential understanding of religion. The third type of religious studies, whilst being scientific in approach, does not constitute a distinct discipline. It is the empirical study of religions carried out by a wide array of other disciplines, including history, sociology, psychology and anthropology. Finally, type 4 is 'a scientific discipline on a par with other scientific disciplines' (p. 120), and unified by the application of theory. This type of religious studies exists more by way of an ideal than a reality, insofar as the study of religion has arguably seen the demise of a coherent body of theory in recent decades (Wiebe 2005, 121).

Given the summary nature of his article, Wiebe does not offer his own view, though I would suggest that he leans towards types 3 and 4 whilst recognising that, given the lack of unanimity on the subject and the demise 
of theory in the post-war period, religious studies has been neither capable of nor committed to transforming itself into an autonomous discipline on a par with others (cf. McCutcheon 2003; Anttonen 2004; Griffiths 2006; Wiebe 2000, 2006). ${ }^{13}$ Wiebe's own typology, like Ford's, may be represented as a continuum, in this case with a conflation between religious studies and theology at one end (Type 1), a radical disciplinary separation of the two at the other (Type 4 ) and two intermediary positions.

\section{Insider/Outsider Issues and the Relationship of Theology and Religious Studies}

In looking briefly at how two scholars have summarised 'theology' and 'religious studies' and at how they have typologised the various approaches to these disciplines, it has become clear that a variety of views are held about their interrelationship all of which have different spatial implications. In the diagrams I have presented so far the aim has been to reflect the place of 'religion' within various academic approaches. Those that follow show some of the relationships between theology and religious studies that we have read about so far. They are based on the metaphorical principle that disciplines are conceived as 'containers', something that is borne out by the repeated use of spatial metaphors with reference to inside/outside, boundaries, inclusion/exclusion, integration and embrace. As has been clear, power runs through all these relationships: theology and religious studies are not always conceived as equal partners or innocent neighbours.

One discipline can be portrayed as wholly containing the other (Fig. 4a); they can be seen as distinctive and separate disciplines with different objects, goals and motivations (4b); they can be envisaged as largely separate but partially overlapping (4c); they can both be contained within a larger meta-discipline (e.g., 'the study of religions') (4d); one can be distinguished from the approach that pre-dated it (4e); one can 'embrace' the other (4f); or the embrace can be mutual $(4 \mathrm{~g})$.

In the remainder of this section I will focus more closely on the language of containment, of 'inside' and 'outside', ${ }^{14}$ with its implications of commu-

\footnotetext{
${ }^{13}$ In a recent article, in which Wiebe critically assesses the intentions and aims encapsulated within presidential addresses of the American Academy of Religion, he ends by considering 'missing voices' from the science of religion. He writes 'a science of religion [...] is not an autonomous enterprise that is ultimately free from the constraints of the other sciences but must rather recognize them as constituting "boundary conditions" that affect the range of theories of religion reasonably open to the Religious Studies enterprise. That is, those theories will have to locate themselves within what might be called an "integrated causal model" of the sciences' $(2006,691)$.

${ }^{14}$ The terms 'insider' and 'outsider' have also been used to refer to standpoint issues within the study of religions (e.g. McCutcheon 1999; Arweck \& Stringer 2002; Knott 2005c). Despite its relevance, I do not discuss this usage here.
} 
nity, power and values, in various representations of religious studies and its relationship to theology.

Tony Becher began his 1989 book, Academic Tribes and Territories: Intellectual Enquiry and the Cultures of Disciplines, with the quotation from F. G. Bailey with which this article opened. He then went on to illustrate and discuss Bailey's account of what makes a tribe in relation to the development of disciplines. ${ }^{15}$ Becher's references to tribe and territory are useful in helping us to think about the disciplines of theology and religious studies:

The tribes of academe, one might argue, define their own identities and defend their own patches of intellectual ground by employing a variety of devices geared to the exclusion of illegal immigrants. Some, as we have noted, are manifest in physical form [...] others emerge in the particularities of membership and constitution [...] Alongside these structural features of disciplinary communities, exercising an even more powerful integrating force, are their more explicitly cultural elements: their traditions, customs and practices, transmitted knowledge, beliefs, morals and rules of conduct, as well as their linguistic and symbolic forms of communication and the meanings they share. $(1989,24 .)^{16}$

Becher refers explicitly to the socio-spatial manifestation of the boundary devices employed by disciplinary communities, as well as to their constitution and the way in which they define themselves in relation to others, sometimes keeping inappropriate outsiders at bay. He also mentions those things which hold an academic tribe or community together or bind it, that integrate it, that can be transmitted to new members, and can be practised. He goes on to note that disciplines have folk myths, founding figures, 'cultural capital' (Bourdieu in Becher 1989, 25), and 'tacit knowledge' (Gerholm in Becher $1989,26)$. These are all aspects which pertain to the 'inside' of disciplines and can be learnt and practised by 'insiders', but which also assist in separating them from 'outsiders', from other disciplinary communities, their beliefs and practices, and the knowledge associated with them.

As Becher states, not all disciplinary communities are alike. Some are 'convergent and tightly knit in terms of their fundamental ideologies, their common values, their shared judgements of quality, their awareness of belonging to a unique tradition' (p. 37), and, as such, they are likely to

\footnotetext{
${ }^{15}$ Much of what he says is about the distinctiveness of such academic communities and the knowledges associated with them, but he and others also turn their attention to interdisciplinarity (cf. Moran 2002).

${ }^{16}$ It would be extremely interesting to deliberate on such cultural elements as they pertain to the two disciplines at issue here, but this must be the work of other studies.
} 
have 'well-defined external boundaries' (p. 37) to protect themselves from outsiders. He uses the words 'heresy', 'expulsion', 'alien' and 'resistance' to describe them. Other groupings are 'divergent and loosely knit'; they lack 'a clear sense of mutual cohesion and identity' (p. 37), are less likely to police their boundaries, and more likely to overlap with other disciplinary groupings. In presenting various types of theology and religious studies respectively, both Ford and Wiebe suggested that the disciplines could be defined and practised in various ways, some more convergent, tightly knit and resistant to outsiders; others less so. Closed boundaries were a feature of two of Ford's five types, and Wiebe's type 4 (Fig. 3) certainly aspired to autonomous disciplinary status (whilst not yet achieving it), convergent upon theories of religion. The other types represented more loosely bounded and divergent approaches to the study of religion.

However, given its history and the way in which it is presented in introductory books, I would suggest that, generally, theology is the more 'convergent' of the two disciplines. It is the more focused, having been understood 'as systematic analysis of the nature, purposes and activity of God' (McGrath 2001, 138). Many theology books, including Ford's own Theology: A Very Short Introduction (1999), begin with God. Most of those who write about the nature of theology as a discipline refer to Anselm on 'faith seeking understanding', to the inseparability of faith and inquiry, to faith and reason, or belief and analysis. They refer to its 'architecture': biblical studies, systematic theology, historical theology, pastoral theology, philosophical theology, spirituality or mystical theology. Yes, some of these branches, and the scholars who work within them, are more or less open to other disciplines, whether religious studies, another humanities subject or a social science, but they are in general agreement about these core issues, these integrating factors.

This is certainly not the pattern with religious studies. Even if we leave aside Wiebe's first two types (theology under new management and religious studies as tertiary RE, see Fig. 3) and concentrate on the social scientific modes of the discipline, it appears to be divergent. We would find it difficult to identify common theories, methodology, practices, norms and structures upon which the majority of scholars could agree. And it is for this very reason that, as Wiebe notes, no formally autonomous discipline of religious studies has yet emerged. The concepts 'religion' and 'religions' are central, of course, if much contested, but otherwise the discipline is notable for its plurality of methods and theories, the majority of which have been developed 'outside' the new enterprise of religious studies, in 
other disciplines (hence the not infrequent reference to religious studies as a 'magpie' among the disciplines). Indeed, some of the very approaches and theories that have been most notably associated with the 'inside' of religious studies have been the most hotly contested: i.e., phenomenology, approaches to religious experience, and the work of Otto, Wach, Eliade and Smart. Religious studies as a discipline does not have an agreed 'corporate intelligence' (Anttonen 2004, 105; cf. Capps 1995) or well developed body of theory (Wiebe 2005, 121). It is no doubt for these reasons that the term 'field' is preferred to 'discipline', there being relatively open field boundaries, a diversity of methodologies present, and little by way of an agreed core or focus. 'Who, if anyone, cannot be invited to table: who, if anyone, is to be excluded?', asks Steven Sutcliffe (2004, xviii-xix). He goes on to suggest that the chief motivating factor continues to be the relationship with theology. Is theology the uninvited guest? Should it be included or excluded? And, indeed, what exactly counts as theology? Citing Glyn Richards, Sutcliffe writes that religious studies has often operated with a monolithic representation of 'Christian theology', 'as a sharply differentiated, taboo "other", standing over against a purified "Religious Studies"' (p. xx).

Even though theology has often been presented glibly by religious studies scholars as the 'straw man to knock down' (Sutcliffe 2004, xx), when we look more closely at the work of those who have sought specifically to understand and describe the relationship we see a more informed approach that for some presents grounds for the inclusion and for others the exclusion of theology at the scholarly table. Timothy Fitzgerald, despite his sustained criticism of the ecumenical liberal theology at work within religious studies, has no particular axe to grind about traditional theology as a separate discipline with its own integrity, goals and methods $(2000,7)$.

June O'Connor, who has referred to academic theology as 'truthclaimology', sees it rather differently, as 'a component of religious studies' $(1997,84)$ in so far as both theology and religious studies employ critical reasoning in pursuit of knowledge and understanding about religion. 'Theological or truthclaimological inquiry and analysis' she writes, 'furthers the academic mission of religious studies, and is thus appropriately placed within it, not only as data, but also as method' (p. 85).

Gavin Flood, in search of a way out of the phenomenological impasse in religious studies, recognises the similarities between contemporary academic theology and religious studies. They are both 'kinds of writing about religion, with convergence and divergence, and both arise from the practice of rational method' $(1999,19)$. They do, however, constitute different types 
of discourse, with theology being 'an internalized discourse' (p. 22) about something 'of which it is itself $a$ part' (p. 22) whereas religious studies is 'a language about religion' (p. 20), an externalized discourse.

Arnal and Braun, in a move which counters $\mathrm{O}^{\prime}$ Connor's position and could be said to build on those of Fitzgerald and Flood, propose that the designation, category and discipline of 'religion' be returned to the ownership of theology (in press, 6), with secular disciplines studying those objects that are inside the 'Religion circle' as non-theological objects. As a manner of classifying things, 'religion', they say, is intrinsically theological, even though the things themselves are 'amenable to humanistic or social-scientific analysis outside the confines of Religion as such, i.e. as independent non-religious objects of various disciplinary scrutinies' (p. 5).

These scholars have very different views about the theology/religious studies relationship which become apparent when we see their views represented spatially. Whilst Fitzgerald recognises 'traditional theology' as a legitimate discipline situated outside religious studies, he is critical of the enemy within: theology in its ecumenical, liberal guise (Fig. 5). Such is the role of this guise in the historical development and current constitution of religious studies that Fitzgerald argues for cultural studies rather than religious studies as the proper, independent arena for the academic investigation of 'religion' (2000, 221-34). O'Connor expresses no such fears, preferring to see congruence between religious studies and academic theology in their use of critical reasoning for the study of religion, and situating the latter inside the broader, more inclusive former (Fig. 6), thus reversing the 'embrace' suggested by Ford $(2005,66)$. Flood, too, notes this congruence, which, for him, focuses on discursive strategies, but marks the difference between the two in terms of internalization (theology) or externalization (religious studies) (Fig. 7). In the assessment of Arnal and Braun, the secular academy has failed to pursue its own scientific principles in researching (or 'appropriating') those non-theological objects that religionists categorize as 'religious', and has continued to give reverence and 'living space' to 'religion' on its own, theological terms (in press, 7-8). The role of the secular academy in this matter should rather be contrapuntal: it should reflexively deconstruct the scholarly concept of 'religion' (p. 9) (Fig. 8).

All of these scholars find different ways of dealing with the boundary between theological and non-theological studies of religion. In so doing, they draw attention to some of the interesting properties of disciplinary boundaries: the potential contagion arising from a porous, loosely defined boundary (Fitzgerald), the potential artificiality of disciplinary boundaries 
where methods and objects of study are held in common ( $\mathrm{O}^{\prime}$ Connor), the different discursive possibilities generated by the existence of a scholarly boundary (Flood), and the potentially transgressive incursions of those disciplines that cross the boundaries of others (Arnal and Braun).

\section{Spatial Language, Boundaries and the 'Sacred': A Conclusion}

In analysing the language of their relationship, I have only taken the first step in a spatial analysis of theology and religious studies. A full analysis would require a more systematic consideration of these disciplines as social and physical as well as discursive spaces. But what has this initial analysis offered? It has brought to our attention the spatial language at work in discourse in English about the discipline of religious studies and its relationship with theology, ${ }^{17}$ and has suggested the following points:

- There are competing spatial representations of the relationship between the disciplines, as the diagrams have shown.

- The territory of 'religion' as an object of study is contested; it is marked by continuous struggle.

- One commonly used knowledge-power strategy is that of containment; the notion of 'embrace' suggests mutuality, but may also be experienced as an expression of dominance.

- The 'insides' of the two disciplines (RS and T) are differently conceived in terms of their objects of study, beliefs and practices, academic and methodological traditions, mission and purpose. Religious studies is the more loosely bounded and divergent of the two.

- There are differing views about the nature of the boundary between them, about who and what can be accommodated on either side of it and who and what must be excluded, and about the scholarly possibilities generated by the maintenance and/or dissolution of the boundary.

All the views about religious studies presented here - and the many others on this subject that have not been considered - contribute to the reproduction of a dynamic knowledge-power field in which disciplinary struggle occurs for many reasons. From time to time the various parties are locked in battle over methodological or standpoint issues, or because they disagree about the object of study, but at other times they agree to join forces against external

\footnotetext{
${ }_{17}$ A similar spatial analysis could be conducted of discourse in other languages about the nature of religious studies and its relationship to theology. Relationships between religious studies and other disciplines, such as anthropology or cognitive studies, could also be examined.
} 
threats (even, at times, with theology).$^{18}$ I would suggest that, much like the religious and secular facets of the western cultural order in which their relationship has been forged, religious studies and theology are historically and discursively intertwined and are mutually-imbricated. Arguably, they are like twins, part of the same body, ever bound to one another though sometimes striving to be free and to experience themselves as separate and distinctive. As such, they cannot help but struggle with one another. The boundary between them is a liminal space across which they are attracted and repelled. It is a boundary of transition: when it is approached and sometimes transgressed the 'other' must be engaged, in play or discussion, in fight or embrace, or in an act of consumption.

As we have seen, such boundaries, in marking the inside and outside of territories, are expressions of power. In so far as they mark categorical differences, they also acquire the attribution of 'sacrality'. As Veikko Anttonen has said, 'it is the notion of a category boundary that establishes the "sacred" and the difference it makes' $(2005,198)$. Such a boundary constitutes those things which are non-negotiable, pure and sacrosanct, as well as forbidden and taboo. In the case of theology and religious studies, the boundary brings to the fore categorical issues such as the centrality of 'God' or 'religion' and their totemic significance, the place of faith, belief, value and truth in the scholarly enterprise, and critical questions of objectivity, empirical reality and the scientific process. Not that it is a fixed, solid or immoveable boundary (though some might prefer it to be that way). Like other disciplinary boundaries, it is open to incursion and transgression, to interdisciplinary moves and, as we have seen, to visions of engagement, marriage and dissolution. All such breaches involve change. They involve acknowledging or even becoming the 'other' in some way, however temporary or partial a step this might be.

Drawing on the scholarly conception of the 'sacred' in the final part of this spatial analysis might be felt to be inappropriate, even offensive, by scholars on one side of the boundary, and ironic, ambiguous and possibly dangerous, by those on the other. Nevertheless, as Anttonen has noted, it is precisely the observation of 'the actions, events and intentions of cultural agents as they make distinctions between spaces, mark them for specific uses, create visible and invisible boundaries, and establish cultural conventions of behaviour to deal with those boundaries' (Anttonen 2005, 198) that allows this scholarly notion of the 'sacred' to be theorized. In this sense the

${ }^{18}$ This has occurred frequently in Britain when departments have been threatened with closure, or when government and other public bodies have introduced new mechanisms for audit and assessment. 
disciplinary and institutional discourses and practices of scholars of religion themselves become data for the development of the scholarly concept of the 'sacred' and its application in secular as well as religious contexts.

\section{Bibliography}

\section{Anttonen, Veikko}

1996 Rethinking the Sacred: The Notions of 'Human Body' and 'Territory' in Conceptualizing Religion. - Thomas A. Idinopulos \& Edward A. Yonan (eds), The Sacred and its Scholars: Comparative Religious Methodologies for the Study of Primary Religious Data, 36-64. Leiden and Boston: E. J. Brill.

2004 Pathways to Knowledge in Comparative Religion: Clearing Ground for New Conceptual Resources. - Timothy Light \& Brian C. Wilson (eds), Religion as a Human Capacity: A Festscrift in Honor of E. Thomas Lawson, 105-20. Leiden and Boston: E. J. Brill.

2005 Space, Body, and the Notion of Boundary: A Category-Theoretical Approach to Religion. - Temenos 41:2, 185-202.

\section{Arnal, William E. \& Willi Braun}

in press. Does Theology Belong in Religious Studies? - Brad Verter and Johannes C. Wolfart (eds), Rethinking Religion 101: Critical Issues in Religious Studies. Cambridge: Cambridge University Press.

\section{Arweck, Elisabeth \& Martin Stringer (eds)}

2002 Theorizing Faith: The Insider/Outsider Problem in the Study of Ritual. Birmingham: University of Birmingham Press.

\section{Asad, Talal}

1993 Genealogies of Religion: Disciplines and Reasons of Power in Christianity and Islam. Baltimore: Johns Hopkins University Press.

\section{Becher, Tony}

1989 Academic Tribes and Territories: Intellectual Enquiry and the Culture of Disciplines. Milton Keynes: The Society for Research into Higher Education and the Open University.

\section{Bourdieu, Pierre}

1988 Homo Academicus. Cambridge: Polity Press.

\section{Capps, Walter}

1995 Religious Studies: The Making of a Discipline. Minneapolis: Fortress Press.

\section{Corrywright, Dominic \& Peggy Morgan}

2006 Get Set for Religious Studies. Edinburgh: Edinburgh University Press. 


\section{Fitzgerald, Timothy}

2000 The Ideology of Religious Studies. New York and Oxford: Oxford University Press.

Flood, Gavin

1999 Beyond Phenomenology: Rethinking the Study of Religion. London and New York: Cassell.

\section{Ford, David}

1999 Theology: A Very Short Introduction. Oxford: Oxford University Press.

2005 Theology. - John Hinnells (ed.), The Routledge Companion to the Study of Religion, 61-79. London and New York: Routledge.

Griffiths, Paul J.

2006 On the Future of the Study of Religion in the Academy. - Journal of the American Academy of Religion 74:1, 66-74.

Hinnells, John (ed.)

2005 The Routledge Companion to the Study of Religion. London and New York: Routledge.

Hufford, David J.

1999 The Scholarly Voice and the Personal Voice: Reflexivity in Belief Studies. - Russell T. McCutcheon (ed.), The Insider/Outsider Problem in the Study of Religion: A Reader, 294-310. London and New York: Cassell.

\section{Johnson, Mark}

1987 The Body in the Mind: The Bodily Basis of Meaning, Imagination and Reason. Chicago and London: Chicago University Press.

\section{Knott, Kim}

2005a The Location of Religion: A Spatial Analysis. London and Oakville CT: Equinox.

2005b Spatial Theory and Method for the Study of Religion. - Temenos, 41:2, 153-84.

2005c Insider/Outsider Perspectives in the Study of Religions. - John Hinnells (ed.) The Routledge Companion to the Study of Religion, 243-58. London and New York: Routledge.

\section{Lakoff, George, and Johnson, Mark}

1980 Metaphors We Live By. Chicago and London: University of Chicago Press.

1999 Philosophy in the Flesh: The Embodied Mind and its Challenge to Western Thought. New York: Basic Books.

\section{Lefebvre, Henri}

1991 [1974] The Production of Space. Oxford and Cambridge MA: Blackwell. 


\section{Masuzawa, Tomoko}

2005 The Invention of World Religions: Or, How European Universalism Was Preserved in the Language of Pluralism. Chicago: Chicago University Press.

\section{McCutcheon, Russell T.}

1997 Manufacturing Religion: The Discourse of Sui Generis Religion and the Politics of Nostalgia. New York and Oxford: Oxford University Press.

2003 The Discipline of Religion: Structure, Meaning, Rhetoric. New York and London: Routledge.

2004 Dispatches from the 'Religion' Wars. - Timothy Light \& Brian C. Wilson (eds), Religion as a Human Capacity: A Festscrift in Honor of E. Thomas Lawson, 161-92. Leiden and Boston: E. J. Brill.

McCutcheon, Russell T. (ed.)

1999 The Insider/Outsider Problem in the Study of Religion: A Reader. London and New York: Cassell.

McGrath, Alister E.

2001 Christian Theology: An Introduction. Third edition. Oxford: Blackwell.

Moran, Joe

2002 Interdisciplinarity. London and New York: Routledge.

\section{O'Connor, June}

1997 Taking the Bull by the Tail: Responses to the Lingua Franca Article. - Council of Societies for the Study of Religion Bulletin, 26:4, 78-85.

\section{Schweiker, William}

2006 On the Future of Religious Ethics: Keeping Religious Ethics Religious and Ethical - Journal of the American Academy of Religion, 74:1, 135-51.

\section{Smith, Jonathan Z.}

2004 Relating Religion: Essays in the Study of Religion. Chicago and London: University of Chicago Press.

\section{Sutcliffe, Steven}

2004 Introduction: Qualitative Empirical Methodologies: An Inductive Argument. - Steven Sutcliffe (ed.), Religion: Empirical Studies, xvii-xliii. Aldershot: Ashgate.

\section{Thorne, Stuart}

2006 The Language of War. London and New York: Routledge.

\section{Wiebe, Donald}

1998 The Politics of Religious Studies: The Continuing Conflict with Theology in the University. New York: St Martin's Press. 
2000 Why the Academic Study of Religion? Motive and Method in the Study of Religion. - Tim Jensen \& Mikael Rothstein (eds), Secular Theories on Religion: Current Perspectives, 261-79. Copenhagen: Museum Tusculanum Press.

2005 Religious Studies. - John Hinnells (ed.), The Routledge Companion to the Study of Religion, 98-124. London and New York: Routledge.

2006 An Eternal Return All Over Again: The Religious Conversation Endures. - Journal of the American Academy of Religion, 74:3, 674-696.

\section{Appendix: Figures}

Figure 1: Academic perspectives on religion in The Routledge Companion to the Study of Religion

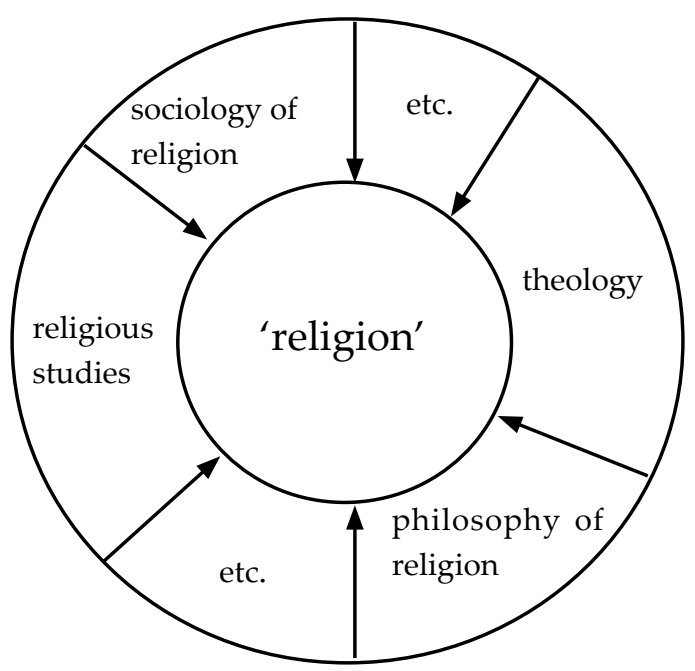


Figure 2: Ford on theology as questions raised by, about, between religions

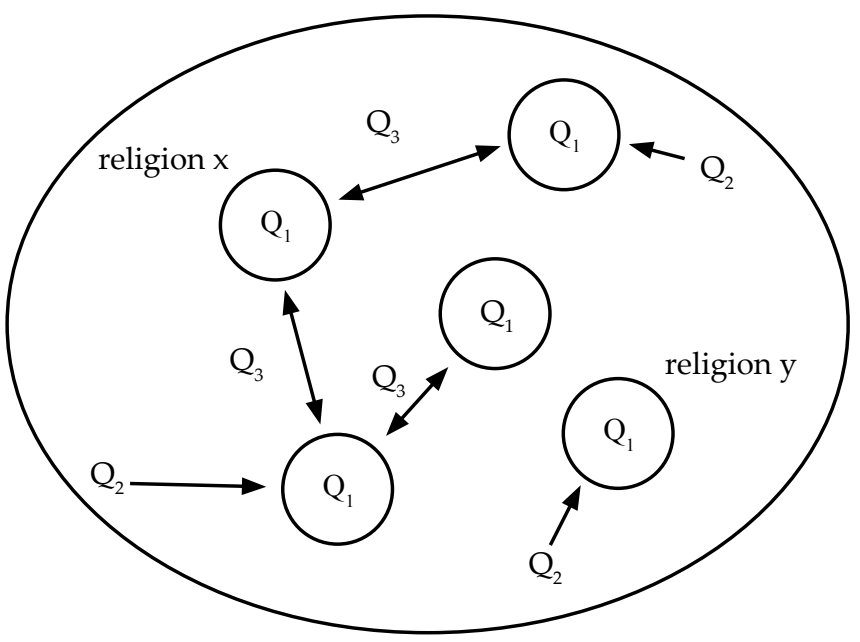

Figure 3: Wiebe's four types of religious studies: 1. RS as theology; 2. RS as religious education; 3 . RS as empirical and scientific studies of religion; 4 . $\mathrm{RS}$ as an autonomous scientific discipline.
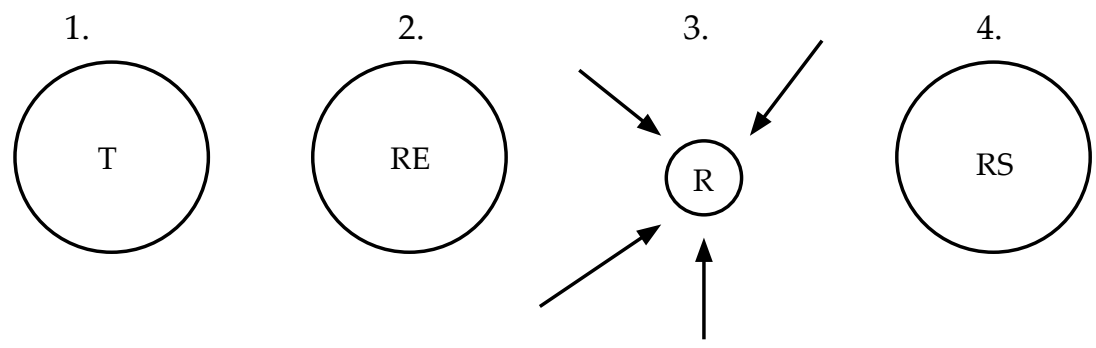
Figure 4: Spatial representations of possible relationships between theology and religious studies

$4 a$

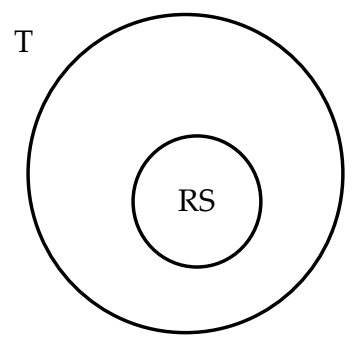

$4 c$

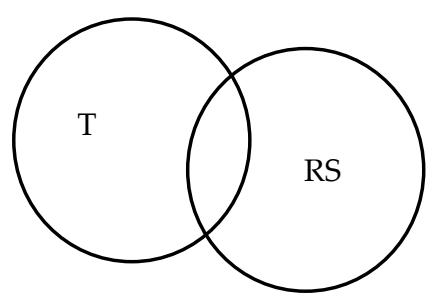

$4 e$

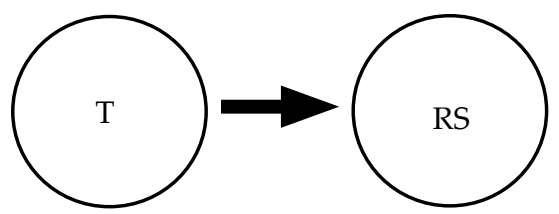

$4 \mathrm{~g}$

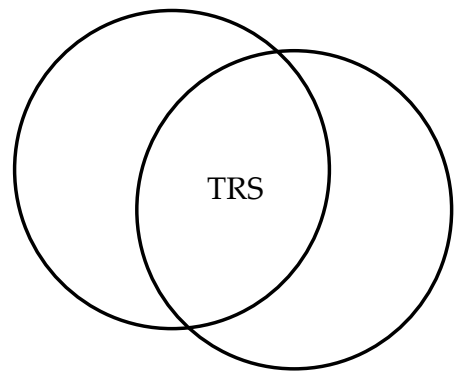

$4 b$
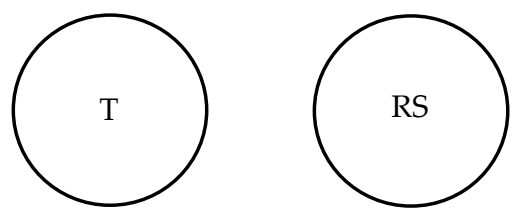

$4 d$

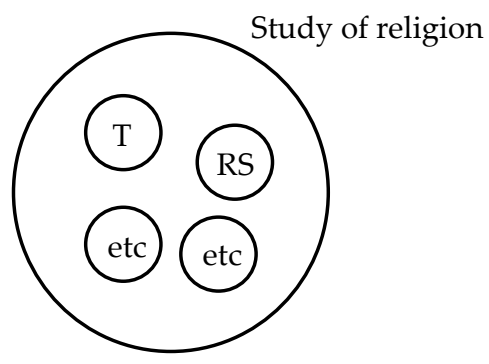

$4 f$

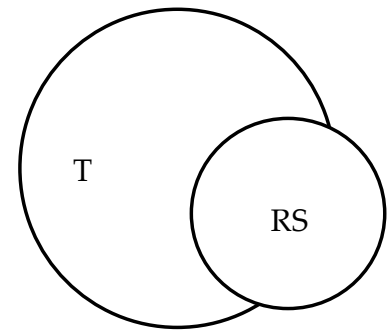


Figure 5: Fitzgerald's view of the relationship between theology and religious studies

TT: Traditional theology

RS: Religious studies

ELT: Ecumenical liberal theology
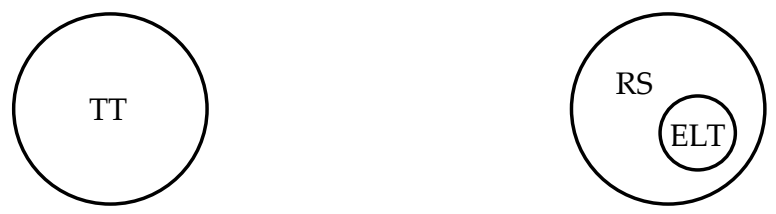

Figure 6: $\mathrm{O}^{\prime}$ Connor's view of the relationship between theology and religious studies

RS: Religious studies

AcT: Academic theology

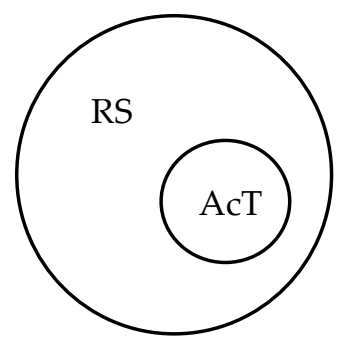

Figure 7: Flood's view of the relationship between religion, theology and religious studies

RS: Religious studies as externalised discourse

$\mathrm{T}$ : Theology as internalised discourse

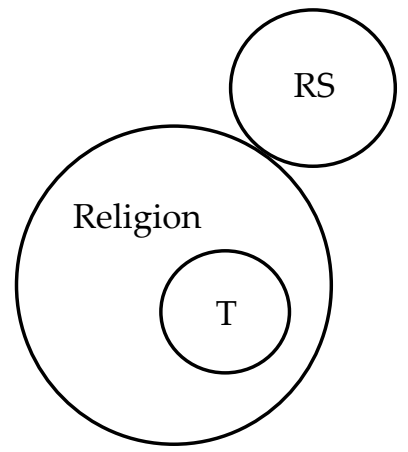


Figure 8: Arnal and Braun's view of the relationship between religion, theology and the secular academy

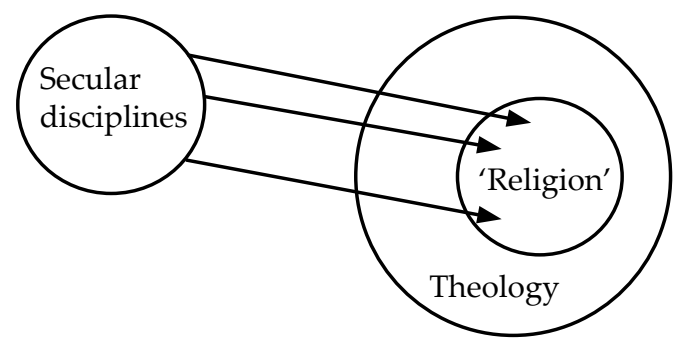


